\title{
Negative emissions of carbon dioxide through chemical-looping combustion (CLC) and gasification (CLG) using oxygen carriers based on manganese and iron
}

\author{
Tobias Mattison, et al. [full author details at the end of the article]
}

Received: 2 July 2018 / Accepted: 21 March 2019 / Published online: 27 April 2019

(C) The Author(s) 2019

\begin{abstract}
Carbon capture and storage (CCS) is an economically attractive strategy for avoiding carbon dioxide $\left(\mathrm{CO}_{2}\right)$ emissions from, e.g., power plants to the atmosphere. The combination of CCS and biomass combustion would result in a reduction of atmospheric $\mathrm{CO}_{2}$, or net negative emissions, as plant growth is a form of sequestration of atmospheric carbon. Carbon capture can be achieved in a variety of ways, one of which is chemical looping. Chemical-looping combustion (CLC) and chemical looping gasification (CLG) are two promising technologies for conversion of biomass to heat and power or syngas/methane with carbon capture. There have been significant advances made with respect to CLC in the last two decades for all types of fuel, with much less research on the gasification technology. CLG offers some interesting opportunities for production of biofuels together with carbon capture and may have several advantages with respect to the bench mark indirect gasification process or dual-bed fluidized bed (DFBG) in this respect. In CLG, an oxygen carrier is used as a bed material instead of sand, which is common in indirect gasification, and this could have several advantages: (i) all generated $\mathrm{CO}_{2}$ is present together with the syngas or methane in the fuel reactor outlet stream, thus in a concentrated stream, viable for separation and capture; (ii) the air reactor (or combustion chamber) should largely be free from trace impurities, thus preventing corrosion and fouling in this reactor; and (iii) the highly oxidizing conditions in the fuel reactor together with solid oxide surfaces should be advantageous with respect to limiting formation of tar species. In this study, two manganese ores and an iron-based waste material, LD slag, were investigated with respect to performance in these chemical-looping technologies. The materials were also impregnated with alkali $(\mathrm{K})$ in order to gauge possible catalytic effects and also to establish a better understanding of the general behavior of oxygen carriers with alkali, an important component in biomass and biomass waste streams and often a precursor for high-temperature corrosion. The viability of the oxygen carriers was investigated using a synthetic biogas in a batch fluidized bed reactor. The conversion of $\mathrm{CO}, \mathrm{H}_{2}, \mathrm{CH}_{4}$, and $\mathrm{C}_{2} \mathrm{H}_{4}$ was investigated in the temperature interval $800-950{ }^{\circ} \mathrm{C}$. The reactivity, or oxygen transfer rate, was highest for the manganese ores, followed by the LD slag. The conversion of $\mathrm{C}_{2} \mathrm{H}_{4}$ was generally high but could largely be attributed to thermal decomposition. The K-impregnated samples showed enhanced reactivity during combustion conditions, and the Mangagran-K sample was able to achieve full conversion of benzene. The interaction of the solid material with alkali showed widely different behavior. The two manganese ores retained almost all alkali after redox testing, albeit exhibiting different
\end{abstract}


migration patterns inside the particles. LD slag lost most alkali to the gas phase during testing, although some remained, possibly explaining a small difference in reactivity. In summary, the CLC and CLG processes could clearly be interesting for production of heat, power, or biofuel with negative $\mathrm{CO}_{2}$ emissions. Manganese ores are most promising from this study, as they could absorb alkali, giving a better conversion and perhaps also inhibiting or limiting corrosion mechanisms in a combustor or gasifier.

Keywords Chemical-looping combustion - Chemical-looping gasification · Oxygen carrier · Manganese ore $\cdot$ Negative emissions

\section{Introduction}

Biomass growth removes carbon dioxide $\left(\mathrm{CO}_{2}\right)$ from the atmosphere through photosynthesis. When the biomass is burnt, the carbon is returned to the atmosphere. However, if the $\mathrm{CO}_{2}$ formed in the combustion is captured and subsequently stored in geological formations, there is a net reduction of $\mathrm{CO}_{2}$ from the atmosphere, i.e., net negative emissions of $\mathrm{CO}_{2}$. This concept is commonly referred to as Bio-energy carbon capture and storage (BECCS), and it is one of the most promising negative emission technologies (NETs). The attractiveness of BECCS is due to a combination of very high potential, reasonable costs, and high security of storage (IPCC 2014).

The key technologies currently being evaluated and developed for $\mathrm{CO}_{2}$ capture, e.g., precombustion, post-combustion, and oxy-fuel, all suffer from the inevitable need of significant gas separation work. These steps involve added operational costs as well as large energy penalties. Gas separation processes are generally mature technologies, and no major technology breakthrough is foreseen. This is in great contrast to chemical-looping combustion (CLC), a form of unmixed combustion and the focus of this paper. Here, $\mathrm{CO}_{2}$ separation is inherent to the process, see Fig. 1 (left). CLC is probably the only technology we know today where a significant breakthrough could be envisaged for avoiding the large costs and energy penalty of gas separation in $\mathrm{CO}_{2}$ capture. A variant of normal CLC is chemical looping with oxygen uncoupling, or CLOU. Here, the oxygen carrier releases oxygen to the gas phase in the fuel reactor, enhancing fuel conversion (Abad et al. 2012; Mattisson et al. 2009). In addition to full combustion for heat and power production, the chemical-looping technology can also be adapted for gasification purposes, see Fig. 1 (right). Here, only partial oxidation is achieved in the fuel reactor, with the aim of maximizing the conversion to syngas, i.e. $\mathrm{CO}$ and $\mathrm{H}_{2}$, a common feed-stock for fuels and chemicals (He et al. 2013). This is similar to the more conventional Dual-Fluidized Bed Gasification (DFBG) or indirect gasification, where sand or olivine is normally used as the bed material, and used for transferring heat from the combustion chamber to the gasification reactor (Larsson et al. 2014; Marinkovic et al. 2015). Another similar application using oxygen carriers is chemical-looping reforming of tars, here denoted CLTR, a down-stream conditioning system (Lind et al. 2011).

The use of an oxygen carrier in chemical-looping gasification (CLG) could have several advantages in comparison to conventional indirect gasification:

- All generated $\mathrm{CO}_{2}$ can be formed in the fuel reactor, see Fig. 1 (right). In normal indirect gasification, the carbon dioxide is generated primarily in the combustion chamber, or air reactor and hence diluted with nitrogen. Thus, in CLG, a more concentrated stream of $\mathrm{CO}_{2}$ is generated 
together with the syngas, applicable for separation and storage. It should be pointed out that even in indirect gasification, there will be some $\mathrm{CO}_{2}$ generated in the gasifier, hence a carbon removal step is always going to be needed prior to the fuel production.

- Partial oxidation of the fuel with the oxygen carrier could enhance conversion of hydrocarbons to syngas.

- The higher $\mathrm{H}_{2} \mathrm{O}$ and $\mathrm{CO}_{2}$ concentrations in the fuel reactor in comparison to indirect gasification will likely mean less tar formation (Larsson et al. 2014).

- Oxygen carrier particles may provide additional sites for catalytic reforming reactions.

As biomass is a limited resource, sources of decreased quality will likely be the most applicable to use in chemical-looping systems, including refuse, and municipal and agricultural wastes. From a carbon utility point of view, it would also be beneficial to use wastes, rather than pure woody biomass. However, these types of fuel often include highly aggressive and toxic impurities, e.g., $\mathrm{K}, \mathrm{Cl}, \mathrm{Pb}$. These species are problematic in normal thermal conversion systems with respect to fouling, corrosion, and toxic emissions. This leads to an additional important advantage of using chemical looping:

- Chemical looping could provide a solution for much cleaner conversion of wastes, as the fuel reactor may provide a sink for the impurities, keeping the air reactor - and hence the main exhaust gas flow - clean and free from corrosive components, see Fig. 1. This is likely especially important for alkali and chlorine compounds, common precursors for high-temperature corrosion in biomass-fired systems (Boström et al. 2012).

Most operational experience with respect to chemical-looping combustion and chemical looping with oxygen uncoupling (CLOU) have been conducted with fossil-based fuels, such as coal or natural gas (Mattisson et al. 2018). Research with biomass as fuel has increased during the last few years, likely as a result of the possibility to achieve negative emissions, e.g., Adánez-Rubio et al. 2018, Schmitz and Linderholm 2018. However, some earlier operational experience has been reported, e.g., Mendiara et al. 2013, Shen et al. 2009. With respect to CLG-utilizing biomass, also here, there is limited operational experience. The CLG of biomass (rice husk) was investigated in a continuous setup with two interconnected fluidized beds using natural hematite mixed with sand as an oxygen carrier and steam as a gasification agent in the fuel reactor (Ge et al. 2016a, b). A high yield to syngas was reported in these studies. Almost all of the reported operation of CLC and CLG with biomass have used natural ores or
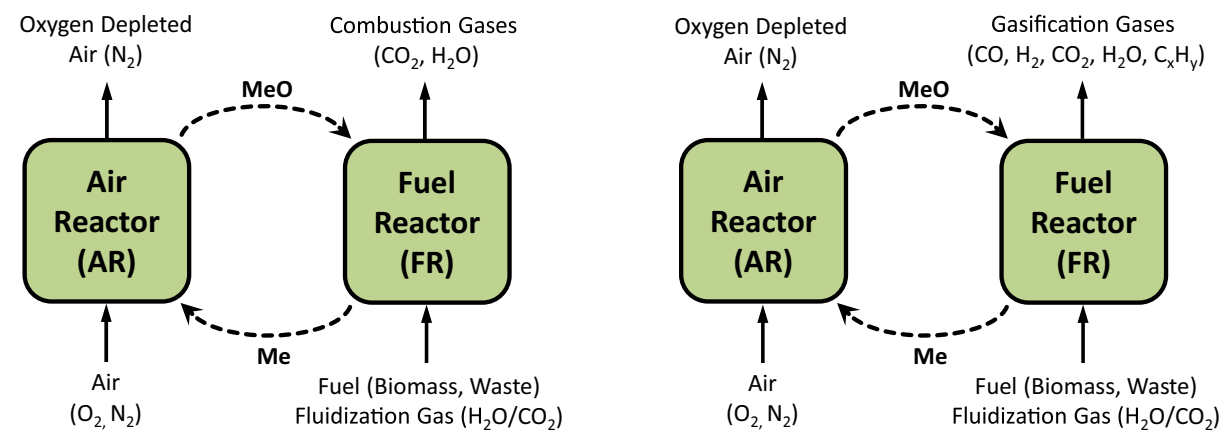

Fig. 1 Chemical-looping combustion (left) and chemical-looping gasification (right) 
wastes based on Fe or Mn as oxygen carriers, although some operation has also been performed with manufactured materials (Mattisson et al. 2018). A recent review of chemical-looping technologies with biomass has been provided by Mendiara et al. (2018).

This work provides an investigation of manganese ore and an iron-based oxygen carrier with respect to chemical-looping combustion and chemical-looping gasification. These materials were evaluated with respect to conditions important for these systems, such as reactivity with $\mathrm{CH}_{4}, \mathrm{CO}$, and $\mathrm{H}_{2}$ at different degrees of solid and gaseous conversion. In addition, the reactivity with tar-precursors $\mathrm{C}_{2} \mathrm{H}_{4}$ and $\mathrm{C}_{6} \mathrm{H}_{6}$ were established at different degrees of oxidation. Further, several of the materials were impregnated using potassium, in order to establish the effect of such components on the gas conversion, but also to establish how the alkali behaves in the oxygen carrier during the redox process.

\section{Experimental}

\subsection{Materials}

The bed materials used in the experiments included two manganese ores, Sinaus and Mangagran, previously used in CLC experiments using continuous units, (Linderholm et al. 2017; Schmitz et al. 2016) and in batch fluidized beds (Sundqvist et al. 2017). Further, LD slag, a by-product from the steel production process, and delivered by SSAB Merox, was investigated in this study. This material has also been investigated previously with respect to chemical-looping tar reforming (Keller et al. 2014). All samples were calcined at $1070{ }^{\circ} \mathrm{C}$ in air. Three samples were also impregnated with $\mathrm{K}_{2} \mathrm{CO}_{3}$, indicated by the denotation sample- $K$ in Table 1. This was done in order to establish possible effects of alkali during the redox cycles with fuel and oxygen, but also to establish the fate of the alkali in the solid sample. The elemental analysis of the test samples can be found in Table 1. Evidently, the impregnation resulted in samples with $\mathrm{K}$ in the range 4-7 wt\%. All samples were sieved to a size range of $125-180 \mu \mathrm{m}$ before use in the batch fluidized bed reactor, see the next section.

\subsection{Experimental setup and procedure}

The experiments were carried out in a single fluidized-bed quartz reactor. An overview of the system can be found in previous works (Keller et al. 2016). In brief, the reactor inner diameter is $22 \mathrm{~mm}$ with the oxygen carrier particles placed on a porous plate in the middle of the reactor. This plate also acts as the distributor plate, as the reducing and oxidizing gases are introduced

Table 1 Elemental analysis of oxygen carriers, given in wt $\%$

\begin{tabular}{lrrrrrr}
\hline Material & Mn & Fe & Si & Al & Ca & K \\
\hline Sinaus & 53.1 & 8.1 & 3.5 & 2.4 & 0.9 & 0.9 \\
Sinaus-K & 49.3 & 7.9 & 3.2 & 2.3 & 0.8 & 5.6 \\
Mangagran & 59.7 & 3.6 & 1.6 & 2.6 & 0.2 & 0.4 \\
Mangagran-K & 54.5 & 2.6 & 1.3 & 2.1 & 0.1 & 6.6 \\
LD slag & 2.4 & 13.9 & 5.1 & 0.5 & 29.7 & 0.0 \\
LD slag-K & 2.7 & 13.9 & 5.0 & 0.5 & 26.5 & 4.0 \\
\hline
\end{tabular}

All analyses were performed using ICP-MS 
from the bottom of the reactor. The entire reactor is enclosed in a furnace, and the temperature was measured inside the bed with a K-type thermocouple enclosed in a quartz cover. The pressure drop over the reactor was measured by Honeywell pressure transducers.

The experiments were conducted with $10 \mathrm{~g}$ of bed material with a size range of 125$180 \mu \mathrm{m}$. Experiments with an empty reactor were conducted in order to understand the gas phase reactions, i.e., to gauge possible non-catalytic and thermal-induced conversion of tar precursors in the gas. In all the experiments, the bed material was exposed to cyclic reducing and oxidizing atmosphere to emulate the circulation in a real chemical-looping unit.

The experiment started with heating in the inert $\left(\mathrm{N}_{2}\right)$ flow of $1.0 \mathrm{~L}_{\mathrm{n}} / \mathrm{min}$. When the temperature reached $800{ }^{\circ} \mathrm{C}$, the inert flow was replaced with a flow of $0.6 \mathrm{~L}_{\mathrm{n}} / \mathrm{min}$ synthetic air. The oxidation period was $1000 \mathrm{~s}$ and even longer sometimes to ensure the material was fully oxidized. After full oxidation and another period of inert gas flow, the bed material was exposed to a synthetic gasification gas flow of $1.0 \mathrm{~L}_{\mathrm{n}} / \mathrm{min}$ and the oxygen carrier here was reduced. This period lasted for 600 to $800 \mathrm{~s}$ to ensure that the conversion of gasification gas at different oxidation potentials of bed material was established, from very oxidized to totally reduced material. This was then followed by an inert and an oxidizing period; the latter was approximately $400 \mathrm{~s}$ in length. This procedure was repeated for three cycles at different temperatures. The composition of the synthetic gasification gas mixture is listed in Table 2. Clearly, there are several species, which may be common in a bulk fuel reactor including biomass, i.e., $\mathrm{CO}, \mathrm{H}_{2}$, and $\mathrm{CH}_{4}$. The latter is an important component, as it is likely harder to convert compared to syngas components. In addition, the inlet gas includes $\mathrm{C}_{2} \mathrm{H}_{4}$, previously used to investigate how different oxygen carriers will behave with respect to the conversion of tar components (Keller et al. 2014).

The bed material which showed the best conversion of $\mathrm{CH}_{4}$ and $\mathrm{C}_{2} \mathrm{H}_{4}$ was investigated also with benzene $\left(\mathrm{C}_{6} \mathrm{H}_{6}\right)$ in the fuel gas feed. Thus, the majority of the experiments were conducted without benzene present. The benzene was introduced to the reducing gas by passing a $\mathrm{N}_{2}$ gas stream through a flask containing $\mathrm{C}_{6} \mathrm{H}_{6}$ after which the gas mixture was cooled to $6{ }^{\circ} \mathrm{C}$ to obtain the saturation concentration of $\mathrm{C}_{6} \mathrm{H}_{6}$ in $\mathrm{N}_{2}$ at this temperature. Hence, condensation of $\mathrm{C}_{6} \mathrm{H}_{6}$ at room temperature could be avoided. The gas stream of $\mathrm{N}_{2}+\mathrm{C}_{6} \mathrm{H}_{6}$ was then mixed with the gasification gas mixture and steam, and the flow of $\mathrm{N}_{2}$ was adjusted to keep the concentrations of all other gases constant.

All experiments were carried out at atmospheric pressure, and 3 cycles were performed at the same temperature to establish repeatability. The temperature was varied between 800 and $950{ }^{\circ} \mathrm{C}$ for both oxidation and reduction. In order to obtain a good resolution of the activity as a function of time, degree of oxidation, and solids reduction, all gaseous components were measured every $4 \mathrm{~s}$ during the experiment. In the paper, results for the second cycle will be shown, unless otherwise indicated.

Table 2 Gas used during the reduction period

\begin{tabular}{ll}
\hline Compound & Concentration (mol\%) \\
\hline $\mathrm{H}_{2} \mathrm{O}$ & 25 \\
$\mathrm{CO}$ & 10.75 \\
$\mathrm{CO}_{2}$ & 3.73 \\
$\mathrm{H}_{2}$ & 5.78 \\
$\mathrm{CH}_{4}$ & 3.5 \\
$\mathrm{C}_{2} \mathrm{H}_{4}$ & 1.25 \\
$\mathrm{C}_{6} \mathrm{H}_{6}$ & 0 or $1.4 \%$ \\
$\mathrm{~N}_{2}$ & Balance \\
\hline
\end{tabular}




\subsection{Gas analysis}

All the pipes before the cooler were heated with heating bands to avoid condensation. The wet flue gas was sent to the heated gas cell of a Thermo-Scientific IS50 FTIR system first. The concentration of $\mathrm{CO}, \mathrm{CO}_{2}, \mathrm{CH}_{4}, \mathrm{C}_{2} \mathrm{H}_{4}, \mathrm{C}_{6} \mathrm{H}_{6}$, and $\mathrm{H}_{2} \mathrm{O}$ were measured by FTIR which was carefully calibrated for the quantitative experiments. After the FTIR, the flue gas was cooled to remove the steam and then analyzed by a dry gas analyzer (NDIR) to measure the concentrations of $\mathrm{H}_{2}$ and $\mathrm{O}_{2}$.

\subsection{Material characterization}

For all solid materials, the BET surface area and pore volume were measured by $\mathrm{N}_{2}$ adsorption using a Micromeritics, TriStra 3000, both prior and after the experiments. The major phases of the bed materials were determined using powder X-ray diffraction (Bruker D8 advance) with $\mathrm{CuK} \alpha$ radiation. The samples were also analyzed by scanning electron microscopy with energy dispersive X-ray spectroscopy (SEM/EDX) in an FEI Quanta 200 Field Emission Gun ESEM equipped with the Oxford Inca EDX system.

\subsection{Data evaluation}

The conversion of the various hydrocarbons $\mathrm{C}_{x} \mathrm{H}_{y}, \gamma_{\mathrm{C}_{x} \mathrm{H}_{y}}$, is calculated from a molar balance of the inlet $\mathrm{C}_{x} \mathrm{H}_{y}$ and the outflowing $\mathrm{C}_{x} \mathrm{H}_{y}$ as determined by FTIR measurement as:

$$
\gamma_{\mathrm{C}_{x} \mathrm{H}_{y}}=\frac{x_{\mathrm{C}_{x} \mathrm{H}_{y}, \text { in }} \dot{n}_{\text {in }}-x_{\mathrm{C}_{x} \mathrm{H}_{y}, \text { out }} \dot{n}_{\text {out }}}{x_{\mathrm{C}_{x} \mathrm{H}_{y}, \text { in }} \dot{n}_{\text {in }}} \times 100 \%
$$

where $\dot{n}_{\text {in }}$ and $\dot{n}_{\text {out }}$ are the inlet and outlet molar flow rates to the reactor, respectively. The outlet flow rate was determined from the inlet flow rate as well as knowledge of the gas expansion due to hydrocarbon conversion. The degree of gas oxidation $\varphi$, which describes to which degree the synthetic gasification gas is oxidized by oxygen supplied by the bed material, is calculated from the following equation:

$$
\varphi=1-\frac{\left(\frac{1}{2} x_{\mathrm{CO}, \text { out }}+\frac{1}{2} x_{\mathrm{H}_{2}, \text { out }}+2 x_{\mathrm{CH}_{4}, \text { out }}+3 x_{\mathrm{C}_{2} \mathrm{H}_{4}, \text { out }}+7.5 x_{\mathrm{C}_{6} \mathrm{H}_{6}, \text { out }}\right) \times \dot{n}_{\text {out }}}{\left(\frac{1}{2} x_{\mathrm{CO}, \text { in }}+\frac{1}{2} x_{\mathrm{H}_{2}, \text { in }}+2 x_{\mathrm{CH}_{4}, \text { in }}+3 x_{\mathrm{C}_{2} \mathrm{H}_{4}, \text { in }}+7.5 x_{\mathrm{C}_{6} \mathrm{H}_{6}, \text { in }}\right) \times \dot{n}_{\text {in }}}
$$

From the outlet gas components and flow, it is also possible to establish the degree of solid reduction, $X_{\text {red, }}$, here defined as:

$$
X_{\mathrm{red}}=\frac{m_{\mathrm{ox}}-m}{m_{\mathrm{ox}}-m_{\mathrm{red}}}
$$

where $m$ is the actual mass of sample, $m_{\mathrm{ox}}$ is the mass of the sample when fully oxidized, and $m_{\text {red }}$ the mass of the sample in the reduced form. In the batch FB, the degree of reduction can be calculated as a function of time from: 


$$
X_{\text {red }}=\frac{\dot{n}_{\text {in } \beta}}{n_{\mathrm{o}}} \int_{t_{0}}^{t_{1}} \varphi d t
$$

where $\beta$ is the oxygen demand of the incoming gas for full combustion and $n_{\mathrm{o}}$ is the number of active moles of oxygen in the solid sample. The oxygen capacity, Ro, was also calculated for the investigated samples:

$$
R_{\mathrm{o}}=\frac{m_{\mathrm{ox}}-m_{\mathrm{red}}}{m_{\mathrm{ox}}}=\frac{n_{\mathrm{o}} M_{\mathrm{o}}}{m_{\mathrm{ox}}}
$$

where $M_{\mathrm{O}}$ is the molar weight of oxygen. The coke formation on the bed material during the reducing period is calculated as the percentage of carbon detected in the oxidation period in relation to the total amount of $\mathrm{C}_{2} \mathrm{H}_{4}$ feed (considering $\mathrm{C}_{6} \mathrm{H}_{6}$ if there is $\mathrm{C}_{6} \mathrm{H}_{6}$ in the feed),

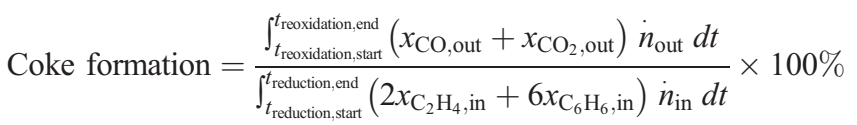

\section{Results}

In Fig. 2, the outlet gas concentrations are presented for an experiment with Mangagran-K as bed material at $900{ }^{\circ} \mathrm{C}$ in the batch fluidized bed reactor. In the beginning of the experiment, the material is exposed to air and can be considered fully oxidized, when the air is replaced with nitrogen. Evidently, the oxygen concentration drops rapidly, but does not completely disappear before the gases are switched to syngas. This is likely due to the capability of the material to release oxygen to the gas phase, or the so-called oxygen uncoupling (CLOU). This

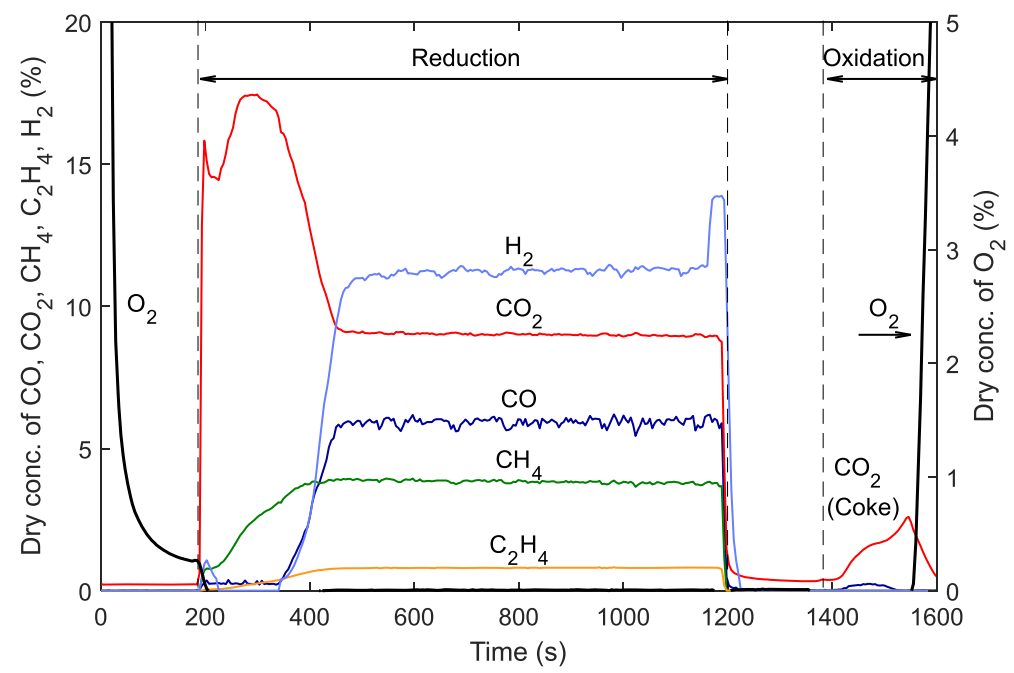

Fig. 2 Gas concentration profile of second redox cycle using Mangagran-K at $900{ }^{\circ} \mathrm{C}$ 
has been seen previously for manganese ores (Sundqvist et al. 2018), but has not been reported earlier for LD slag. Still, looking at the elemental composition in Table 1, it is evident that the presence of $\mathrm{Mn}$ and Fe could result in the formation of mixed oxide phases capable of oxygen uncoupling. After the inert period, the oxidized bed material reacted with the reducing gas, resulting in high peaks of $\mathrm{H}_{2} \mathrm{O}$ (not shown) and $\mathrm{CO}_{2}$, also associated with a high degree of oxidation, as calculated in Eq. (2). This part of the experiment was considered to be of interest for chemical-looping combustion (CLC) because of the considerable oxygen transfer from the bed material to the gas phase. The degree of oxidation decreases as a function of time, until there is no oxygen transfer to the gas phase, i.e., only catalytic reactions are occurring. This period, where there is little or no oxygen transfer, is related to partial oxidation processes, such as chemical-looping reforming (CLR) or chemical-looping gasification (CLG). At the end of the reduction period, there was no oxygen transfer to the gas phase at all, and all reactions can be considered to be catalytic or thermally activated. Afterward, the reactor was flushed with $\mathrm{N}_{2}$ and then the bed material was oxidized by synthetic air. The breakthrough of $\mathrm{O}_{2}$ happened after the coke formed during the experiment that had been oxidized to $\mathrm{CO}_{2}$. The amount of coke formation was relatively small in all experiments, less than $3 \%$ as calculated from Eq. (6) for non-impregnated samples, and it is expected that most coke is formed during the stage when the oxygen carrier is highly reduced.

\subsection{Comparison of reactivity of the three untreated oxygen carriers}

Figure 3 compares the results of the three different non-treated bed materials at $900{ }^{\circ} \mathrm{C}$. The two manganese ores, Mangagran and Sinaus, displayed similar reactivity, as seen with respect to the oxygen transfer to the gas phase, or degree of gas phase oxidation as a function of the degree of solid reduction, Xred, in Fig. 3 a. Here, an oxygen capacity, Ro, defined in Eq. (5) was found to be approximately 0.06 for both manganese ores at this temperature. This should be compared to the theoretical $R_{0}$ of 0.07 for the system $\mathrm{Mn}_{3} \mathrm{O}_{4} / \mathrm{MnO}$ (Johansson 2007). Still, it should be realized that these oxides are not pure, and that mixed oxides are present, and hence, some difference is expected. For the Fe-based material, LD slag, the oxidation rate is considerably lower during the entire reaction, as is clear from Fig. 3 a. The calculated $R_{0}$ was around 0.02 , a value which is considerably lower than that of all pure Fe-oxide systems (Johansson 2007). This is expected, considering the low content of Fe in the sample, see Table 1. It should also be pointed out that the reducing potential $\left(\mathrm{p}_{\mathrm{H} 2} / \mathrm{p}_{\mathrm{H} 2 \mathrm{O}}\right)$ of the incoming gas is not sufficient to reduced iron oxides to the metallic phase Fe. The $\mathrm{C}_{2} \mathrm{H}_{4}$ conversion at this temperature is $30-50 \%$, and highest at higher degrees of oxidation. The methane conversion is very low for all materials as is evident in Fig. $3 \mathrm{c}$. In fact, it is slightly negative for all materials at lower oxidation degrees, perhaps suggesting that the $\mathrm{C}_{2} \mathrm{H}_{4}$ is being converted to $\mathrm{CH}_{4}$ and $\mathrm{C}$, through decomposition. In fact, this was confirmed through analysis of the carbon which was oxidized during the oxidation period. Here, it was seen that there were small amounts of carbon formed for all materials, ranging from $0.5-2.5 \mathrm{wt} \%$, as calculated from Eq. (6). The highest fraction was found to deposit on the LD slag. It is likely that this carbon is formed during the more reducing part of the experiment, in agreement with Fig. 3 c. Still, it should be mentioned that in a real system, it is not expected that the oxygen carrier will be reduced fully, even in a gasification system, and hence, it is not certain that there will be any problems with carbon formation. 

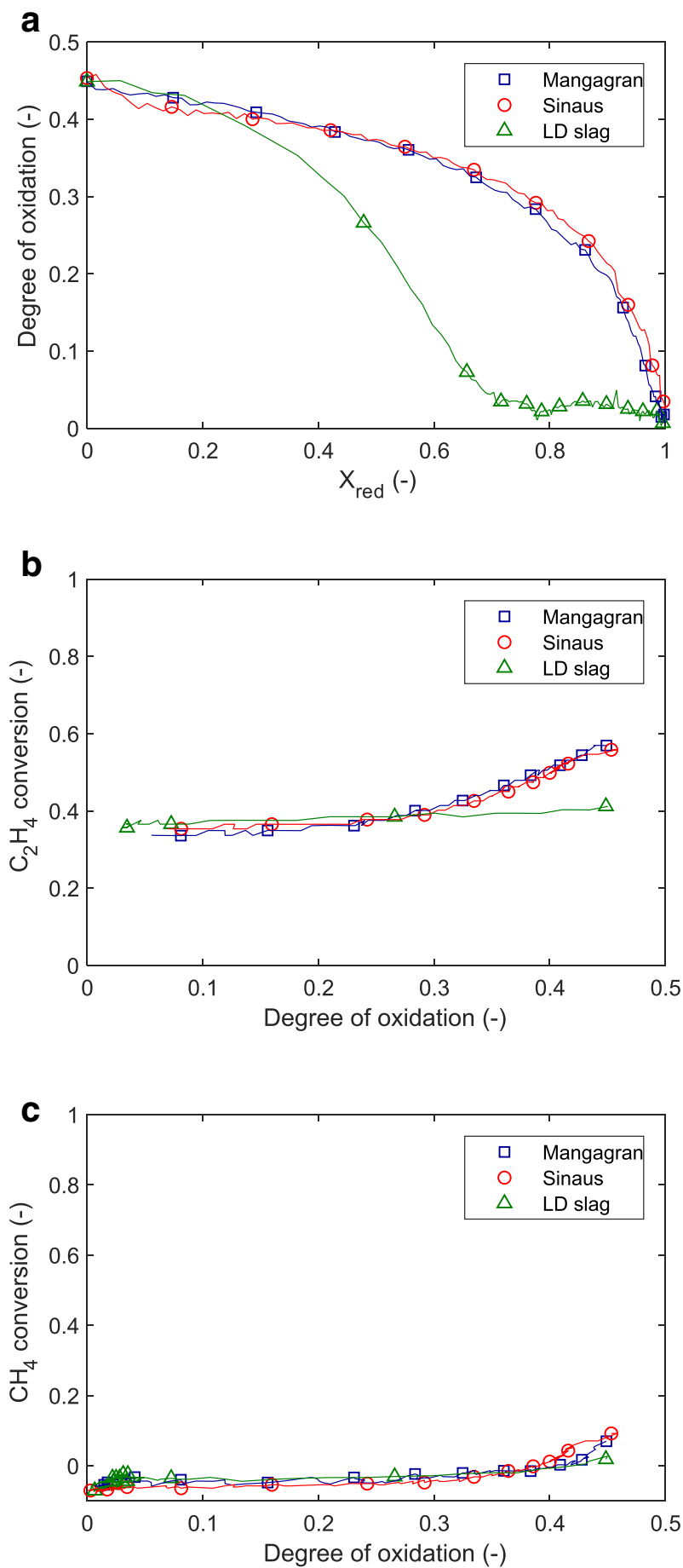

Fig. 3 a The degree of oxidation as a function of the degree of solids reduction, $X_{\text {red }}, \mathbf{b} \mathrm{C}_{2} \mathrm{H}_{4}$ conversion and $\mathbf{c}$ $\mathrm{CH}_{4}$ conversion of three untreated bed materials at $900{ }^{\circ} \mathrm{C}$ 


\subsection{Effect of impregnation with potassium}

From Fig. 4 a, it can be seen that all these three materials obtain a substantially better oxygen transfer rate through impregnation of potassium, here indicated by the initial degree of gas oxidation, as calculated from Eq. (2). The degree of improvement differs, with the Mangagran showing the largest improvement. Figure $4 \mathrm{~b}$ shows the catalytic conversion of $\mathrm{C}_{2} \mathrm{H}_{4}$ as a function of temperature, as determined by the conversion when no oxygen is transferred by the particles. As can be seen, Mangagran-K exhibits the highest conversion, although the effect of impregnation is minor on the conversion of $\mathrm{C}_{2} \mathrm{H}_{4}$ when no oxygen is transferred from the particles.

Figure 5 shows some more detailed results for the most reactive material, the Mangagran manganese ore. Here, the degree of gas oxidation is plotted versus the degree of solid reduction, $X_{\text {red. }}$. The amount of active oxygen was assumed to be constant, with an oxygen capacity, $R_{0}$, of 0.06 , which was calculated for the untreated material at $900{ }^{\circ} \mathrm{C}$, see Fig. 3 a. It is clear that the impregnation of potassium makes a significant improvement in the reactivity, with an increase in the oxygen transfer rate. The reactivity of Mangagran- $\mathrm{K}$ at $800{ }^{\circ} \mathrm{C}$ is even better than the reactivity of the untreated Mangagran at $950{ }^{\circ} \mathrm{C}$. There is some difference in the oxygen capacity, which seems to depend on both the temperature and also the alkali, with the highest oxygen capacity seen at low temperatures with alkali present in the sample. The reason for this enhanced capacity is not clear and could be due to both direct and indirect chemical effects of the alkali components.

The increased reactivity seen with the alkali-impregnated materials is due to enhanced conversion of hydrocarbon components, but could also be due to an enhancement in the water-gas shift reaction. The parameter $Q_{\text {water-gas shift }}=\left[\mathrm{H}_{2}\right]\left[\mathrm{CO}_{2}\right] /[\mathrm{CO}]\left[\mathrm{H}_{2} \mathrm{O}\right]$ was seen to be enhanced for all materials in comparison to the inlet value for the reactant gas, with the alkali materials showing the highest value for $Q$ during the entire reaction, i.e., during the noncatalytic part where the metal oxide provides oxygen, but also during the catalytic part of the reaction. Hence, the increased concentration of $\mathrm{H}_{2}$ may be beneficial for reaction with the oxygen carrier materials, as the species is well-known to react at a fast rate with manganese and iron-based materials.

Figure 6 shows the conversion of $\mathrm{C}_{2} \mathrm{H}_{4}$ and $\mathrm{CH}_{4}$ for Mangagran-K, in comparison with Mangagran as a function of the degree of gas oxidation. Again, it is clear that the impregnation resulted in different behaviors in different periods. The impregnation increases the maximum degree of gas oxidation and, as pointed out previously, also the oxygen capacity at low temperatures. The conversion of $\mathrm{C}_{2} \mathrm{H}_{4}$ and $\mathrm{CH}_{4}$ is thus also enhanced at higher oxidation degrees, but the increase at the same degree of gas oxidation did not vary extensively, when compared with the untreated materials at the same temperature. Thus, the major effect is related to the increased transfer of oxygen, likely a result of enhanced hydrocarbon conversion and water-gas shift reaction.

\subsection{Conversion of benzene $\left(\mathrm{C}_{6} \mathrm{H}_{6}\right)$}

Benzene is well-known to form during biomass gasification and could be formed through different mechanisms, including cracking and reforming of a higher hydrocarbon, or tars. Here, experiments with $\mathrm{C}_{6} \mathrm{H}_{6}$ feed were carried out using Mangagran and Mangagran-K as bed materials, chosen because of their promising behavior with the normal gas mixture. Conversion of $\mathrm{C}_{6} \mathrm{H}_{6}$ as a function of the degree of oxidation is compared between these two materials 

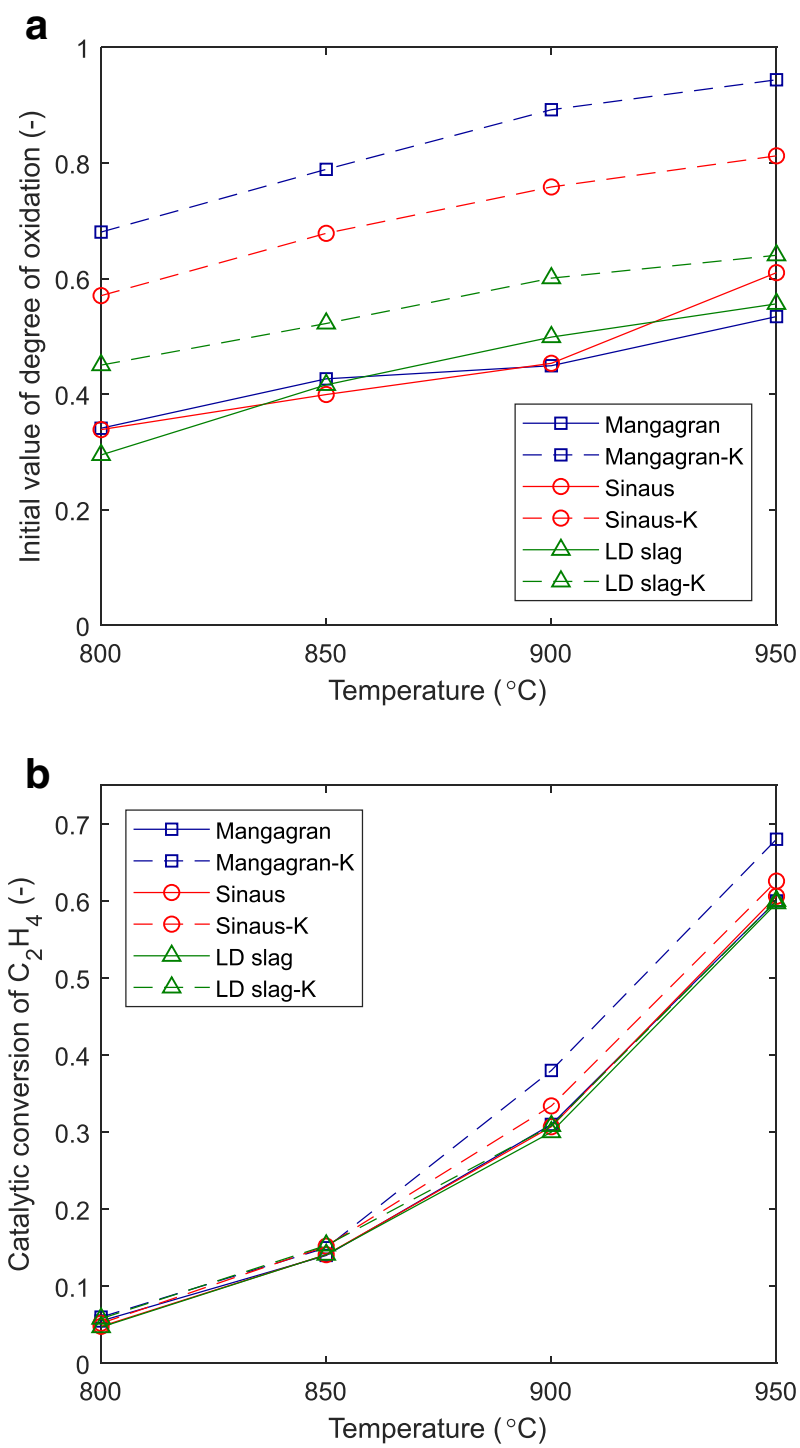

Fig. 4 The comparison of impregnation effect on three different materials - a initial value of the degree of oxidation and $\mathbf{b}$ catalytic conversion of $\mathrm{C}_{2} \mathrm{H}_{4}$

in Fig. 7. The conversion of $\mathrm{C}_{6} \mathrm{H}_{6}$ is improved significantly in the CLC period by the impregnation, similar to $\mathrm{C}_{2} \mathrm{H}_{4}$ and $\mathrm{CH}_{4}$, and full conversion of the benzene is possible at the highest temperature. In the CLR period, the conversion is relatively low compared with $\mathrm{C}_{2} \mathrm{H}_{4}$, and the impregnation plays only a minor role. A higher temperature can increase the conversion a little bit but obviously, $\mathrm{C}_{6} \mathrm{H}_{6}$ is more stable than $\mathrm{C}_{2} \mathrm{H}_{4}$. The effect of $\mathrm{C}_{6} \mathrm{H}_{6}$ feed on the catalytic conversion of $\mathrm{C}_{2} \mathrm{H}_{4}$ and $\mathrm{CH}_{4}$ are presented in Fig. 8. The conversion of $\mathrm{C}_{2} \mathrm{H}_{4}$ increases somewhat, and the formation of $\mathrm{CH}_{4}$ almost doubles. This indicates that $\mathrm{CH}_{4}$ is also a product of $\mathrm{C}_{6} \mathrm{H}_{6}$ decomposition. 


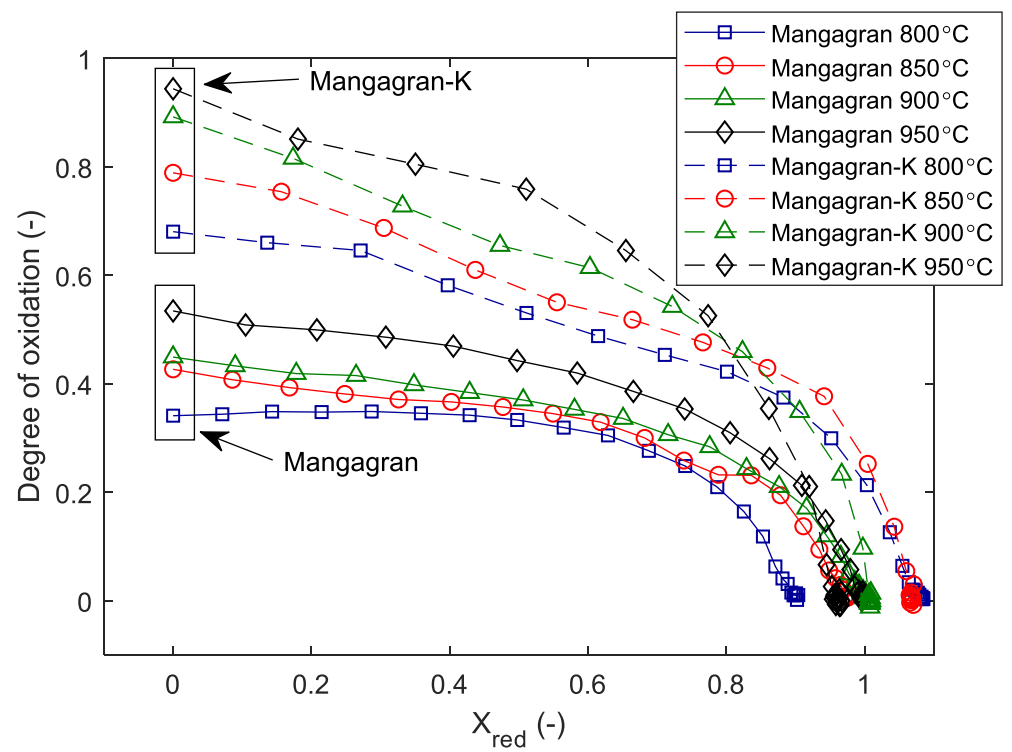

Fig. 5 The degree of gas oxidation as a function of $X_{\text {red }}$ for Mangagran and Mangagran-K at different temperatures

\subsection{Characterization}

One major motivation for this study was to identify not only the effect of alkali on the reactivity, but also to establish the fate of the alkali during the redox testing. Hence, analysis of particles before and after testing was performed using a number of tools. It is important to consider that the particles are natural and waste materials, and SEM/EDX analysis showed that the materials were very heterogeneous, both on a intra- and inter-particle level. As an example, Fig. 9 shows a SEM/EDX mapping for a number of Sinaus-K particles after testing. Table 3 shows the phases of the six samples as determined from the XRD analysis, for both the fresh sample before the experiment and the used samples after the experiment which was finished after an oxidation cycle. Although the phase characterization was difficult due to overlapping and uncertain peaks, it seems as if the potassium is combined within several phases. However, after the experiments, the most prevalent $\mathrm{K}$-compound identified in the manganese ores was $\mathrm{KAlO}_{2}$. For the LD slag, the alkali compounds $\mathrm{KAlSiO}_{4}$ and $\mathrm{K}_{3} \mathrm{P}_{3} \mathrm{O}_{9}$ are identified, but highly uncertain. Interestingly, the LD slag does seem to contain a number of mixed phases of $\mathrm{Fe}-$ Mn, which may explain the small CLOU effect seen in the experiments during the period with nitrogen in the gas phase.

Table 4 shows the results of the BET surface area and pore volume analysis. The BET surface area and the pore volume increased significantly after impregnation for Mangagran and Sinaus, but not for LD slag. The redox cycles result in an increased pore volume and surface area for both untreated and impregnated samples.

To obtain a better understanding of the changes after impregnation, the particles were analyzed using a scanning-electron microscopy (SEM) and energy-dispersive x-ray diffraction (EDX). The analysis was performed on the manganese-based materials only, as these seemed most interesting from an application point of view. Both the surface and interior of the particles were analyzed. With respect to the latter, the particles were cast in epoxy and polished in order 

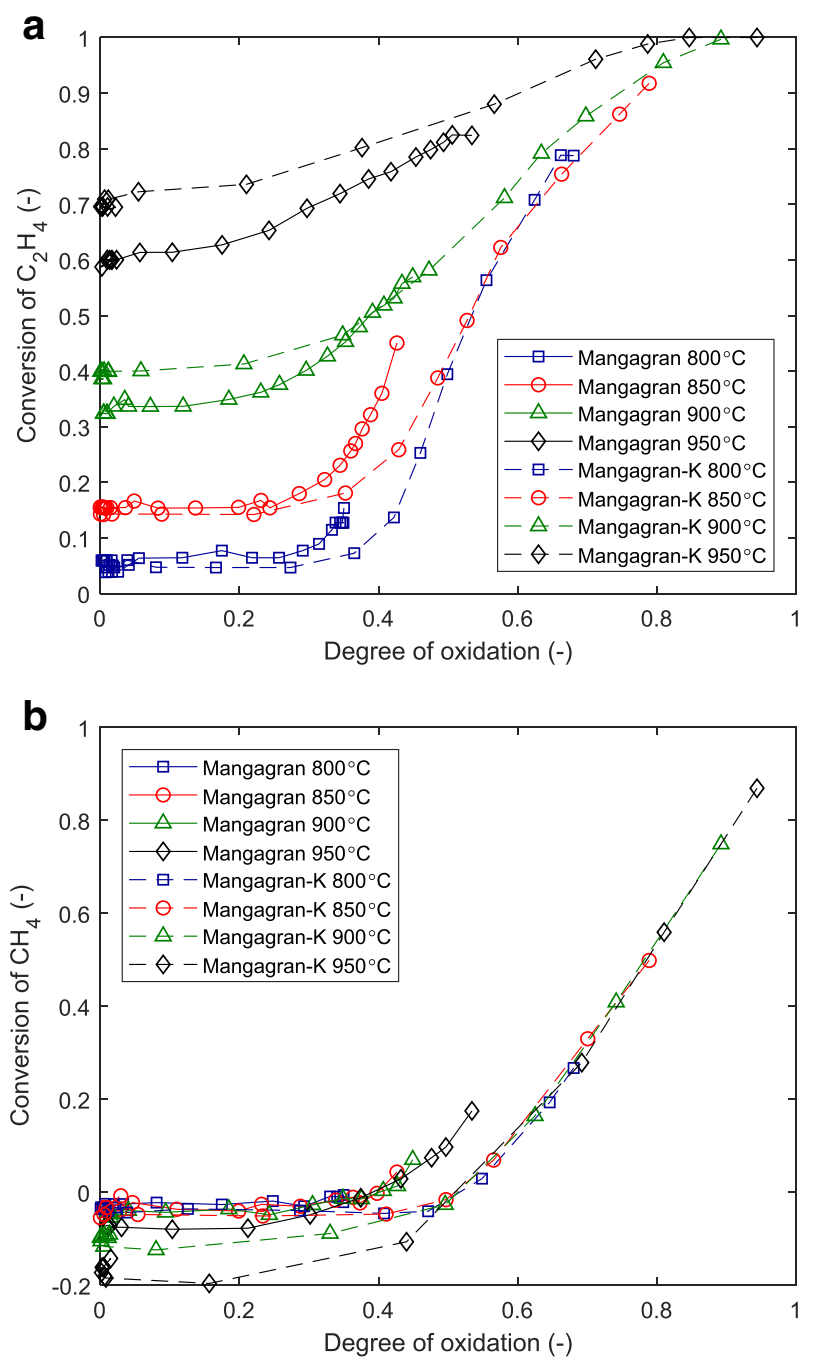

Fig. 6 The $\mathrm{C}_{2} \mathrm{H}_{4}$ and $\mathrm{CH}_{4}$ conversion of Mangagran-K and Mangagran. a $\mathrm{C}_{2} \mathrm{H}_{4}$ conversion. b $\mathrm{CH}_{4}$ conversion

to expose the interior of the particles. Images of Mangagran and Mangagran-K before experiment are compared in Fig. 10. Also, the EDX results are presented in a way of line scan over the selected particle surface. As shown in Fig. 10 (left), the surface of Mangagran is quite compact, corresponding to a small surface area and pore volume, and the potassium content is close to zero, while the $\mathrm{K}$ is well-distributed across the surface for the Mangagran-K, although with a few points with lower concentrations. A comparison of the untreated and impregnated surface shows major difference, and the impregnated sample shows increased grain size of the crystals in comparison to an untreated particle (Fig. 10, right). The BET surface area and pore volume have also been increased greatly by impregnation, as seen in Table 4.

Besides the surface, the cross-section area of the Mangagran-K and Sinaus-K were also investigated, with the main aim to understand the potassium distribution inside the particle. 


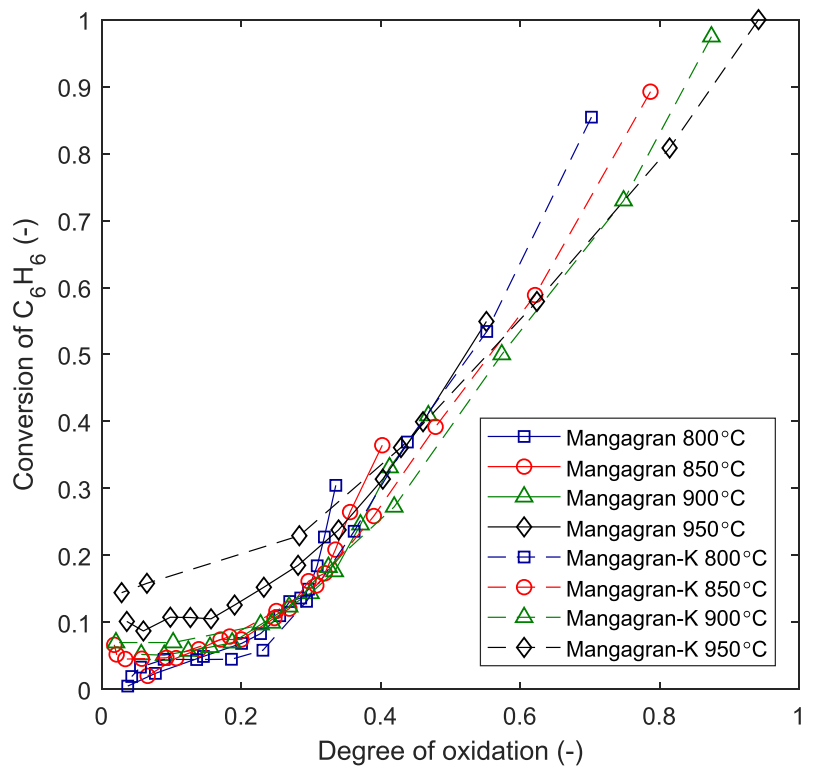

Fig. $7 \mathrm{C}_{6} \mathrm{H}_{6}$ conversion for Mangagran and Mangagran-K

Figure 11 shows the cross-section morphology and the EDX results for these materials before the experiment in the batch fluidized bed. With respect to the latter, entire elemental maps of $\mathrm{Mn}$ and $\mathrm{K}$ (small images) in addition to line scans were retrieved, here also including $\mathrm{Al}$ and $\mathrm{Si}$. For Mangagran, it is evident that the potassium is abundant on the external parts of the particle, while the concentration is generally lower in the central regions. From the mapping images, a similar distribution is evident also in the Sinaus material, although less pronounced

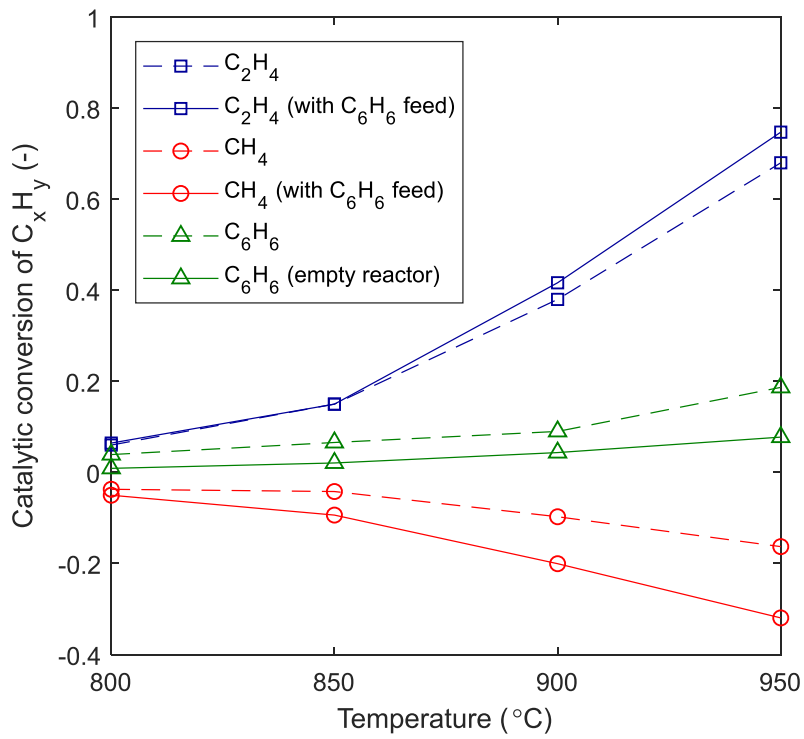

Fig. 8 Catalytic conversion of $\mathrm{CH}_{4}, \mathrm{C}_{2} \mathrm{H}_{4}$, and $\mathrm{C}_{6} \mathrm{H}_{6}$ for Mangagran- $\mathrm{K}$ 

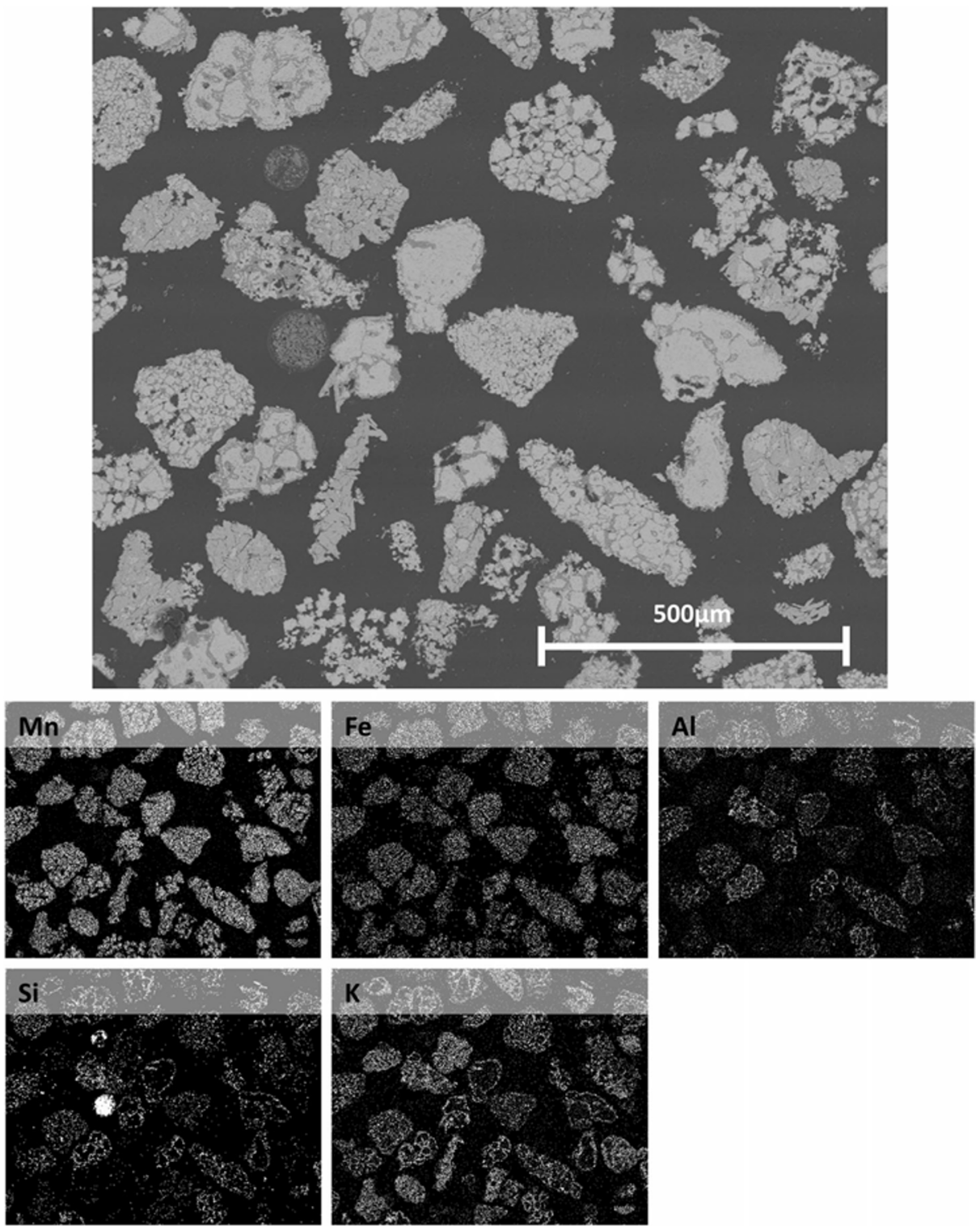

Fig. 9 SEM image of cross section of Sinaus $+\mathrm{K}$ after experiment with EDX mapping (below)

in the particle in Fig. 11. From the line scan analysis, the $\mathrm{K}$ seems to be associated with $\mathrm{Al}$ and $\mathrm{Si}$ in both materials. Thus, it can be concluded that the impregnated potassium is mainly associated with the outer regions of the particles, and then mainly with $\mathrm{Al}$ and $\mathrm{Si}$. The surface area of the manganese ores were magnified significantly in comparison to the untreated ores, which indicates that the impregnation and subsequent calcination have resulted in a physical change, but from these microscopy results, these changes seem to be associated mainly with the surface of the particles. But for LD slag-K, these types of changes were not significant. 
Table 3 Major phases identified by XRD before and after the experiments

\begin{tabular}{|c|c|c|}
\hline Sample & Before experiment & After experiment \\
\hline Mangagran & $\begin{array}{l}\mathrm{Mn}_{3} \mathrm{O}_{4}, \mathrm{Mn}_{2-x} \mathrm{Fe}_{x} \mathrm{O}_{3}, \mathrm{Ca}_{1-x} \mathrm{Mn}_{x} \mathrm{O}, \mathrm{Mn}_{7} \mathrm{SiO}_{12} \\
\quad \alpha-\mathrm{KAlO}_{2}\end{array}$ & $\mathrm{Mn}_{3} \mathrm{O}_{4},\left(\mathrm{Mg}_{1-x} \mathrm{Fe}_{x}\right) \mathrm{SiO}_{4}, \mathrm{Ca}_{3-x} \mathrm{Mn}_{x} \mathrm{Si}_{2} \mathrm{O}_{7}$ \\
\hline Mangagran-K & $\begin{array}{l}\mathrm{Mn}_{3} \mathrm{O}_{4}, \alpha-\mathrm{KAlO}_{2}, \mathrm{~K}_{1.39} \mathrm{Mn}_{3} \mathrm{O}_{6}, \mathrm{~K}<\mathrm{Al}, \mathrm{Fe}> \\
\quad \mathrm{Si}_{2} \mathrm{O}_{8}, \mathrm{~K}_{2} \mathrm{CO}_{3}\end{array}$ & $\mathrm{M}_{0.95} \mathrm{O}, \alpha-\mathrm{KAlO}_{2}$ \\
\hline Sinaus & $\begin{array}{l}\mathrm{Mn}_{7} \mathrm{SiO}_{12}, \mathrm{Ca}_{1-x} \mathrm{Mn}_{x} \mathrm{O}, \mathrm{MnFeO}_{3}, \mathrm{Mn}_{3} \mathrm{O}_{4} \\
\quad \mathrm{Fe}_{3-x} \mathrm{Mn}_{x} \mathrm{O}_{4}\end{array}$ & $(\mathrm{FeO})_{x}(\mathrm{MnO})_{1-x}$ \\
\hline Sinaus-K & $\mathrm{Mn}_{3} \mathrm{O}_{4}, \mathrm{Fe}_{3-x} \mathrm{Mn}_{x} \mathrm{O}_{4}, \alpha-\mathrm{KAlO}_{2}$ & $(\mathrm{FeO})_{x}(\mathrm{MnO})_{1-x}, \alpha-\mathrm{KAlO}_{2}$ \\
\hline LD slag & $\begin{array}{l}\mathrm{CaO}, \mathrm{Ca}_{2} \mathrm{SiO}_{4}, \mathrm{Ca}_{3} \mathrm{SiO}_{5}, \mathrm{Mg}_{0,99} \mathrm{Fe}_{0,01} \mathrm{O} \\
\quad \mathrm{Ca}_{2} \mathrm{Fe}_{x} \mathrm{Mn}_{y} \mathrm{Mg}_{z} \mathrm{Si}_{w} \mathrm{O}_{5}, \mathrm{Mg}_{0,6} \mathrm{Mn}_{0,4} \mathrm{Fe}_{2} \mathrm{O}_{4} \\
\quad \mathrm{~K}_{3} \mathrm{P}_{3} \mathrm{O}_{9}, \mathrm{SiO}_{2}\end{array}$ & $\begin{array}{l}\mathrm{CaO}, \mathrm{Ca}_{2} \mathrm{SiO}_{4}, \mathrm{Ca}_{3} \mathrm{SiO}_{5}, \mathrm{Mg}_{0,99} \mathrm{Fe}_{0,01} \mathrm{O}, \\
\quad \mathrm{Ca}_{2} \mathrm{Fe}_{x} \mathrm{Mn}_{y} \mathrm{Mg}_{z} \mathrm{Si}_{w} \mathrm{O}_{5}, \mathrm{Mg}_{0,6} \mathrm{Mn}_{0,4} \mathrm{Fe}_{2} \mathrm{O}_{4}, \\
\quad \mathrm{~K}_{3} \mathrm{P}_{3} \mathrm{O}_{9}, \mathrm{SiO}_{2}\end{array}$ \\
\hline LD slag-K & $\begin{array}{l}\mathrm{Ca}_{2} \mathrm{SiO}_{4}, \mathrm{Ca}_{3} \mathrm{SiO}_{5}, \mathrm{Mg}_{0,99} \mathrm{Fe}_{0,01} \mathrm{O} \\
\mathrm{Ca}_{2} \mathrm{Fe}_{x} \mathrm{Mn}_{y} \mathrm{Mg}_{z} \mathrm{Si}_{w} \mathrm{O}_{5}, \mathrm{Mg}_{0,6} \mathrm{Mn}_{0,4} \mathrm{Fe}_{2} \mathrm{O}_{4} \\
\quad \mathrm{~K}_{3} \mathrm{P}_{3} \mathrm{O}_{9}, \mathrm{SiO}_{2}\end{array}$ & $\begin{array}{l}\mathrm{Ca}_{2} \mathrm{SiO}_{4}, \mathrm{Ca}_{3} \mathrm{SiO}_{5}, \mathrm{Mg}_{0,99} \mathrm{Fe}_{0,01} \mathrm{O}, \\
\mathrm{Ca}_{2} \mathrm{Fe}_{x} \mathrm{Mn}_{y} \mathrm{Mg}_{z} \mathrm{Si}_{w} \mathrm{O}_{5}, \mathrm{Mg}_{0,6} \mathrm{Mn}_{0,4} \mathrm{Fe}_{2} \mathrm{O}_{4}, \\
\mathrm{~K}_{3} \mathrm{P}_{3} \mathrm{O}_{9}, \mathrm{SiO}_{2}, \mathrm{KAlSiO}_{4}\end{array}$ \\
\hline
\end{tabular}

A similar type of analysis with SEM/EDX was also performed on the two Mn-based materials after the redox experiments at high temperature, Fig. 12. Evidently, there is a major difference in the microstructure as well as the alkali distribution between the two samples. It is obvious that there is a lot of potassium distributed in the entire cross section of the Mangagran- $\mathrm{K}$ after the experiment, which suggests potassium migration during the redox cycles. For Sinaus-K, however, potassium is distributed mainly on the surface, but no significant penetration to interior parts of the particle has occurred. The EDX line scan results clearly show the enhanced alkali content in the central parts for Mangagran, while Sinaus has very low concentrations in the interior (except for one analysis point) while much higher at the edges. As with the fresh sample, the $\mathrm{K}$ in the particles seem to be quite closely associated with the $\mathrm{Al}$ and $\mathrm{Si}$ content.

In order to establish if there is a loss of total alkali from the oxygen carriers, elemental analysis was performed before and after the redox testing, see Fig. 13. As can be seen, there is potassium loss during the experiment for all three materials, although the relative loss varies considerably. For LD slag-K, most of the potassium escapes from the particle to the gas phase. Sinaus-K retains approximately $96 \%$ percent, and Mangagran-K keeps $84 \%$ percent of the potassium. The loss of potassium may be explained by the presence of unstable phases, including phases with low melting points and high volatility, such as $\mathrm{K}_{2} \mathrm{O}, \mathrm{K}_{2} \mathrm{O}_{2}$, and $\mathrm{KO}_{2}$, which have melting points of $878{ }^{\circ} \mathrm{C}, 490{ }^{\circ} \mathrm{C}$, and $535{ }^{\circ} \mathrm{C}$, respectively. For the two manganese ores, most of the potassium remains in the particle, likely due to a stable phase like $\mathrm{KAlO}_{2}$ or $\mathrm{K}-\mathrm{Al}-\mathrm{Si}$ phases, as suggested by the combined XRD and SEM/EDX study.

Table 4 Results of BET surface area and pore volume measurement

\begin{tabular}{llllll}
\hline & \multicolumn{2}{l}{ BET surface area $\left(\mathrm{m}^{2} / \mathrm{g}\right)$} & & \multicolumn{2}{l}{ Pore volume $(\mathrm{mL} / \mathrm{g})$} \\
\cline { 2 - 3 } \cline { 5 - 6 } Name & Before experiment & After experiment & & Before experiment & After experiment \\
\hline Mangagran & 0.16 & 0.89 & 1.8 & 6.3 \\
Mangagran-K & 0.94 & 1.55 & 6.8 & 11.0 \\
Sinaus & 0.072 & 0.84 & 1.2 & 5.7 \\
Sinaus-K & 0.46 & 0.97 & 5.1 & 7.4 \\
LD slag & 0.42 & 0.39 & 3.2 & 3.9 \\
LD slag-K & 0.46 & 0.44 & 3.8 & 3.8 \\
\hline
\end{tabular}




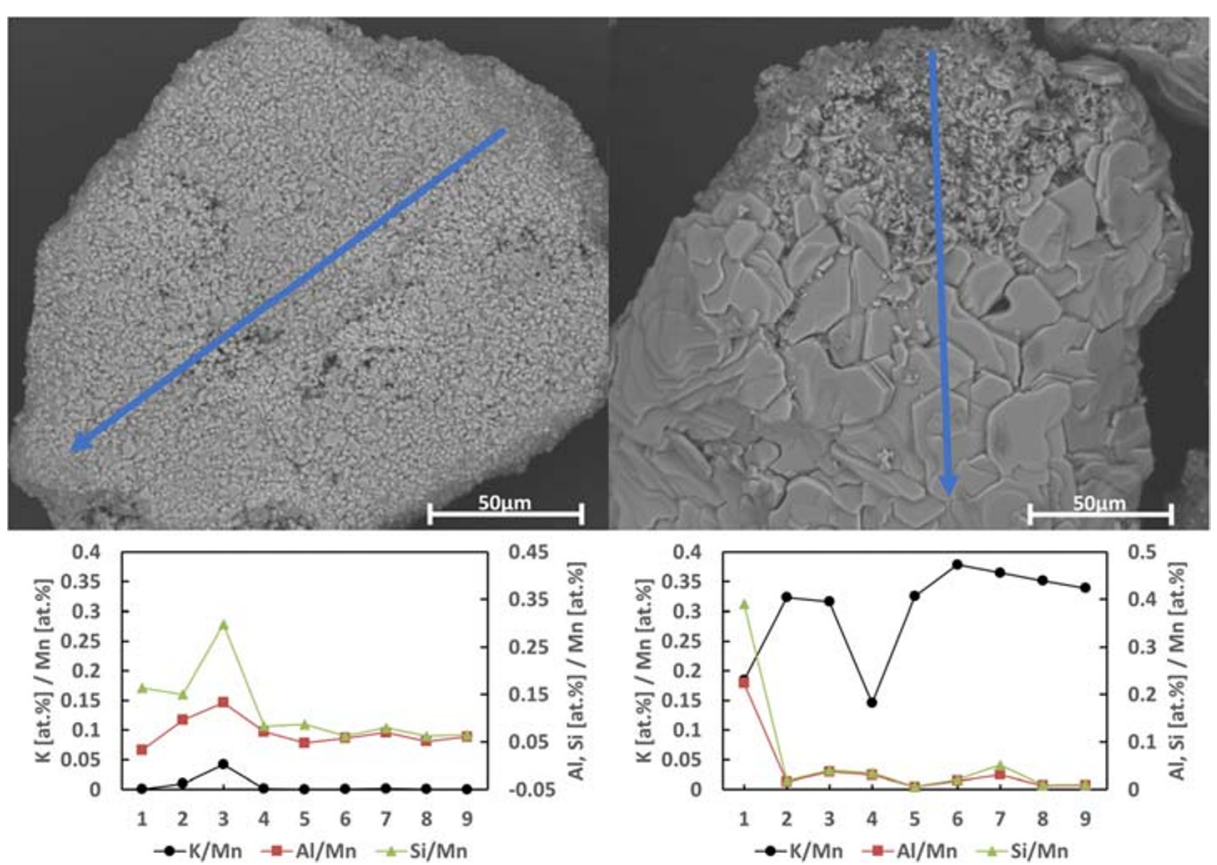

Fig. 10 SEM images and EDX mapping and elemental analysis for Mangagran (left) and Mangagran-K (right) before experiments

\section{Discussion}

Chemical-looping combustion and chemical-looping gasification are two technologies for the production of heat and power or syngas respectively using biomass as fuel. The fact that $\mathrm{CO}_{2}$ is obtained in a relatively concentrated form in the fuel reactor makes the process highly applicable for carbon capture and hence an effective process for achieving negative emissions.
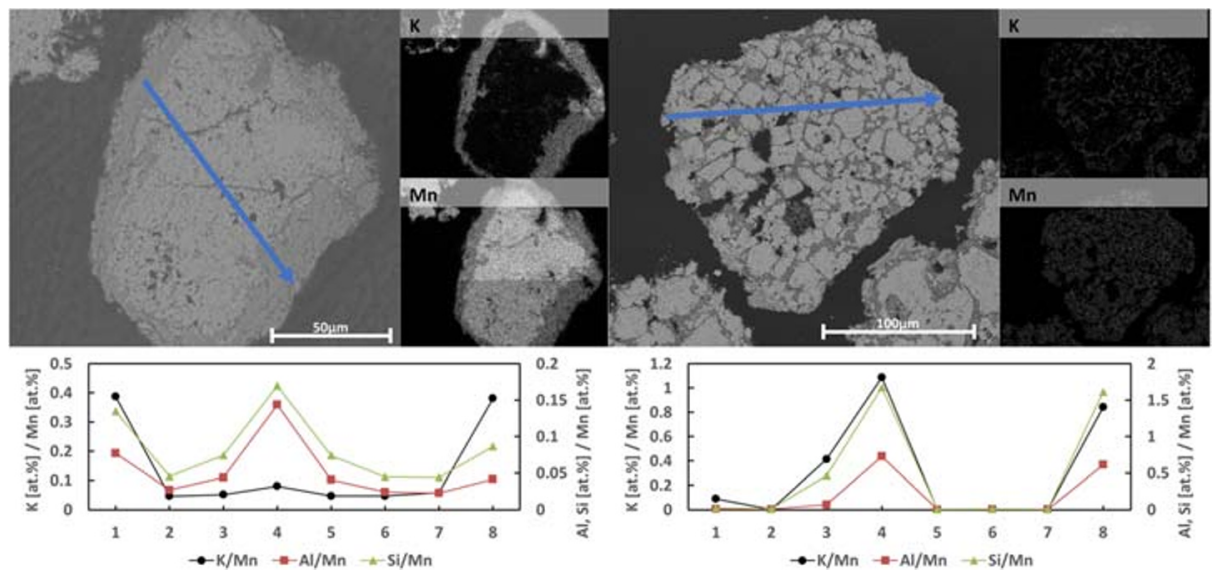

Fig. 11 SEM images and EDX mapping of the interior for Mangagran-K (left) and Sinaus-K (right) before experiments 


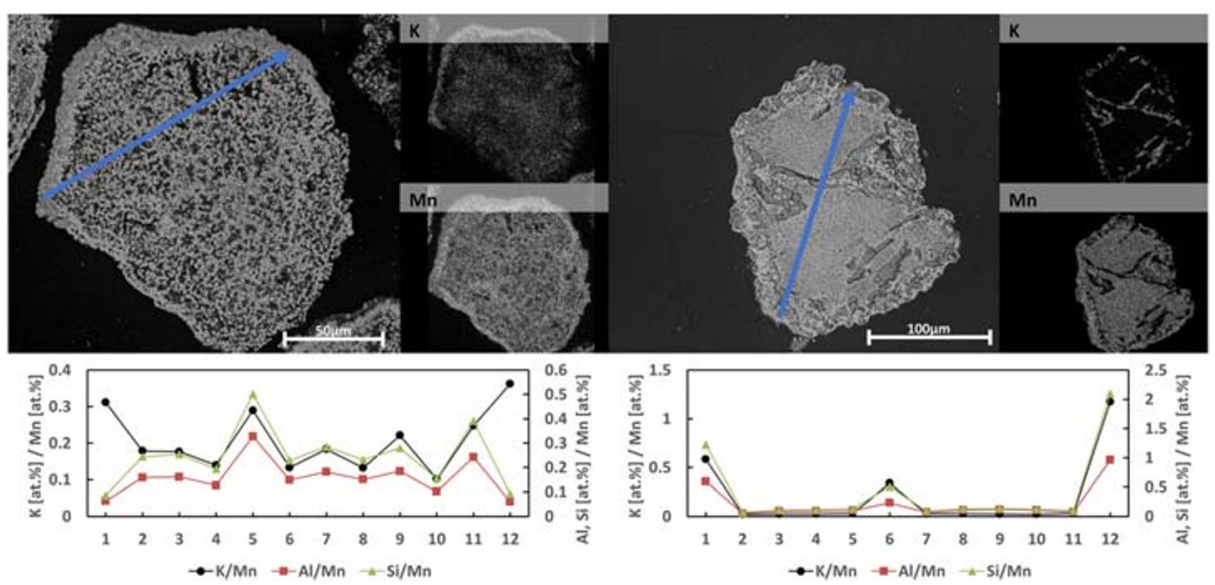

Fig. 12 SEM images and EDX mapping of interior for Mangagran-K (left) and Sinaus-K (right) after experiments

It is likely that such a process will utilize biomass fuels which may contain high fractions of alkali, for instance, agricultural wastes or marine biomass. As ash components could result in deactivation or loss of oxygen carriers with ash flows, it is likely that the most applicable oxygen carriers would be natural materials or waste products. In this work, two manganese ores and one Fe-based waste product were evaluated with respect to use in such a process. The materials were impregnated with alkali $(\mathrm{K})$ which was done in order to gain a better understanding of how oxygen carriers are affected by this compound in a chemical-looping environment. During the experiments, the bed materials were fully reduced to understand its behavior both in the CLC and CLG period. The latter is characterized by a higher degree of oxidation to $\mathrm{CO}_{2}$ and $\mathrm{H}_{2} \mathrm{O}$ in CLC compared with CLG/CLR where only small amounts of oxygen are to be transferred to the gas phase. In the batch reactor, the material was reduced to a point where there is only homogeneous or catalytic reactions occurring. In a real unit, it is expected that there will be some oxygen transfer from the particles as the particles from the air reactor will be oxidized, and it is likely an advantage with respect to obtaining a proper syngas.

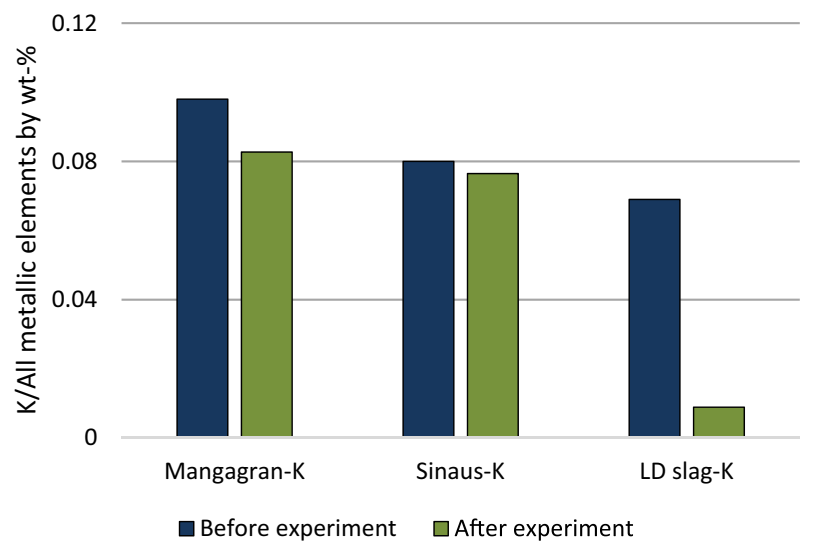

Fig. 13 Weight percentage of potassium in the three impregnated materials before and after the high-temperature experiments 
Generally, the impregnation of potassium can improve the reactivity of the chosen bed materials a lot in the CLC period. In the CLG period, there is no oxygen transfer, and the effect of potassium impregnation on $\mathrm{C}_{2} \mathrm{H}_{4}$ conversion was not significant. Among the three materials, two manganese ores exhibit higher reactivity than LD slag, with higher $\mathrm{CH}_{4}$ and $\mathrm{C}_{2} \mathrm{H}_{4}$ conversion and lower coke formation. This can be explained by a higher degree of oxygen transfer for the manganese ores. From the characterization of materials before and after the experiment, it is found that impregnation did not result in a big change to the LD slag. No stable phases were formed and the surface area did not change significantly. What's more, LD slag-K lost most of the potassium during the experiment, likely due to a lack of higher fractions of inert species such as $\mathrm{Al}$ and/or $\mathrm{Si}$, which can bind the alkali to stable phases.

For both manganese ores, the reactivity in the CLC period is enhanced greatly after impregnation with alkali, and the reactivity with tar precursors was significantly improved here as well. This could be due to several reasons. It is likely that alkali enhances the water-gas shift reaction, producing $\mathrm{H}_{2}$, which usually reacts quite quickly with manganese ores. Further, there is an enhanced reactivity of the hydrocarbon components in the fuel. The enhanced reactivity could in part also be explained by the change of the porosity. The surface area and pore volume become much larger after impregnation. This could help increase the reaction surface for the gas-solid reaction and perhaps also catalyze gas phase reactions. The oxidation reaction of reducing gases and water-gas shift reaction is enhanced in this way.

What is more interesting here is the comparison between the two manganese ores. Actually, the untreated ores behaved in quite a similar way with respect to reactivity. They share a similar increment of surface area and almost the same major phases, as determined from XRD. However, Mangagran-K shows better reactivity than Sinaus-K, converting hydrocarbons better and catalyzing the water-gas shift reaction to a larger extent. The explanation for this difference could be the different behavior of potassium transfer. The elemental analysis shows that Mangagran-K lost more potassium than Sinaus-K. SEM image and EDX line scan of the cross-section area indicates that potassium migrates into the interior of the Mangagran-K particles, thus perhaps enhancing the active sites for catalysis. For Sinaus-K, the migration of potassium is not so extensive. As the mapping suggests that the $\mathrm{K}$ is correlated to alumina-silicates, the migration pattern could be associated with the accessibility of these species in the particle.

The transfer of potassium to the gas phase is likely not optimal because of its corrosivity. Thus, the ability to fix potassium element is vital in practical application. This may have implications also for a chemical-looping system utilizing biomass fuels with high alkali. If the oxygen carrier has the ability to absorb the alkali inside the reactor, this could be beneficial for downstream corrosion. Results in this study indicate that most of the potassium remains in the form of $\mathrm{KAlO}_{2}$ or some type of alumina-silicate clay after the experiment. These type of compounds may have relatively high melting points and thus remains stable during the experiment. Comparatively, LD slag has a much lower aluminum content and this may explain why it lost most of the potassium during testing. Hence, it could be an advantage to use manganese ores with relatively high fractions of $\mathrm{Al}$ and $\mathrm{Si}$ in these systems.

\section{Conclusions}

Chemical looping is highly applicable for use with biomass and biomass wastes and is thus a highly applicable technology to achieve negative emissions. In this paper, three oxygen carriers were investigated with respect to reactivity with biomass-derived gas, including tar 
precursors. Further, the effect of important alkali components was investigated. The main conclusions of this work were:

- The two manganese oxygen carriers showed the highest degree of oxidation in comparison to LD slag, a waste product from the steel industry.

- The impregnation of alkali resulted in improved reactivity during the period where there was oxygen transfer, especially for the manganese ores.

- The increased oxygen transfer also resulted in a higher conversion of tar precursors $\mathrm{C}_{2} \mathrm{H}_{4}$ and $\mathrm{C}_{6} \mathrm{H}_{6}$, and the latter was converted completely by Mangagran- $\mathrm{K}$.

- The fate of alkali in the oxygen carrier during testing varied extensively. For the Mangagran-K, most alkali remained in the particle, but was transferred throughout the particle. For Sinaus manganese ore, most alkali remained after testing but remained near the surface. Finally, the LD slag lost most of the alkali during redox testing.

- Certain oxygen carriers could likely be beneficial for use with high-alkali fuel, as they may react with alkali in the CLC/CLG reactor, which may not only decrease corrosion, but enhance reactivity.

Funding information This project has been supported by grants from the Swedish National Science Foundation (2015-04371) and the Swedish Energy Agency (43220-1).

Open Access This article is distributed under the terms of the Creative Commons Attribution 4.0 International License (http://creativecommons.org/licenses/by/4.0/), which permits unrestricted use, distribution, and reproduction in any medium, provided you give appropriate credit to the original author(s) and the source, provide a link to the Creative Commons license, and indicate if changes were made.

\section{References}

Abad A, Adanez-Rubio I, Gayan P, Garcia-Labiano F, de Diego L, Adanez J (2012) Demonstration of chemicallooping with oxygen uncoupling (CLOU) process in a $1.5 \mathrm{kWth}$ continuously operating unit using a $\mathrm{Cu}-$ based oxygen-carrier. Int J Greenhouse Gas Control 6:189-200

Adánez-Rubio I, Pérez-Astray A, Mendiara T, Izquierdo MT, Abad A, Gayán P, de Diego LF, García-Labiano F, Adánez J (2018) Chemical looping combustion of biomass: CLOU experiments with a Cu-Mn mixed oxide. Fuel Process Technol 172:179-186

Boström D, Skoglund N, Grimm A, Boman C, Öhman M, Broström M, Backman R (2012) Ash transformation chemistry during combustion of biomass. Energy Fuel 26:85-93

Ge HJ, Guo WJ, Shen LH, Song T, Xiao J (2016a) Biomass gasification using chemical looping in a $25 \mathrm{kWth}$ reactor with natural hematite as oxygen carrier. Chem Eng J 286:174-183

Ge HJ, Guo WJ, Shen LH, Song T, Xiao J (2016b) Experimental investigation on biomass gasification using chemical looping in a batch reactor and a continuous dual reactor. Chem Eng J 286:689-700

He F, Galinsky N, Li FX (2013) Chemical looping gasification of solid fuels using bimetallic oxygen carrier particles - feasibility assessment and process simulations. Int J Hydrog Energy 38:7839-7854

IPCC, Climate change (2014) Synthesis Report. Contribution of Working Groups I, II and III to the Fifth Assessment Report of the Intergovernmental Panel on Climate Change, Meyer LA, Pachauri RK, editors. 2014, IPCC: Geneva, Switzerland.

Johansson M 2007 'Screening of oxygen-carrier particles based on iron-, manganese-, copper- and nickel oxides for use in chemical-looping technologies. Doctoral Thesis. ', Chalmers University of Technology

Keller M, Leion H, Mattisson T, Thunman H (2014) Investigation of natural and synthetic bed materials for their utilization in chemical looping reforming for tar elimination in biomass-derived gasification gas. Energy Fuel 28:3833-3840

Keller M, Fung J, Leion H, Mattisson T (2016) Cu-impregnated alumina/silica bed materials for chemical looping reforming of biomass gasification gas. Fuel 180:448-456 
Larsson A, Israelsson M, Lind F, Seemann M, Thunman H (2014) Using ilmenite to reduce the tar yield in a dual fluidized bed gasification system. Energy Fuel 28:2632-2644

Lind F, Seeman M, Thunman H (2011) Continuous catalytic tar reforming of biomass derived raw gas with simultaneous catalyst regeneration. Ind Eng Chem Res 50:11553-11562

Linderholm C, Schmitz M, Biermann M, Hanning M, Lyngfelt A (2017) Chemical-looping combustion of solid fuel in a $100 \mathrm{~kW}$ unit using sintered manganese ore as oxygen carrier. Int J Greenhouse Gas Control 65:170-181

Marinkovic J, Thunman H, Knutsson P, Seemann M (2015) Characteristics of olivine as a bed material in an indirect biomass gasifier. Chem Eng J 279:555-566

Mattisson T, Lyngfelt A, Leion H (2009) Chemical-looping oxygen uncoupling for combustion of solid fuels. Int J Greenhouse Gas Control 3:11-19

Mattisson T, Keller M, Linderholm C, Moldenhauer P, Ryden M, Leion H, Lyngfelt A (2018) Chemical-looping technologies using circulating fluidized bed systems: status of development. Fuel Process Technol 172:1-12

Mendiara T, Abad A, De Diego L, Garcia-Labiano F, Gayan P, Adanez J (2013) Biomass combustion in a CLC system using an iron ore as an oxygen carrier. Int J Greenhouse Gas Control 19:322-330

Mendiara T, García-Labiano F, Abad A, Gayán P, de Diego L, Izquierdo MT, Adánez J (2018) Negative CO2 emissions through the use of biofuels in chemical looping technology: a review. Appl Energy 232:657-684

Schmitz M, Linderholm C (2018) Chemical looping combustion of biomass in 10- and 100-kW pilots - analysis of conversion and lifetime using a sintered manganese ore. Fuel 231:73-84

Schmitz M, Linderholm C, Hallberg P, Sundqvist S, Lyngfelt A (2016) Chemical-looping combustion of solid fuels using manganese ores as oxygen carriers. Energy Fuel 30:1204-1216

Shen L, Wu J, Xiao J, Song Q, Xiao R (2009) Chemical-looping combustion of biomass in a $10 \mathrm{kWth}$ reactor with iron oxide as an oxygen carrier. Energy Fuel 23:2498-2505

Sundqvist S, Khalilian N, Leion H, Mattisson T, Lyngfelt A (2017) Manganese ores as oxygen carriers for chemical-looping combustion (CLC) and chemical-looping with oxygen uncoupling (CLOU). J Environ Chem Eng 5:2552-2563

Sundqvist S, Mattisson T, Leion H, Lyngfelt A (2018) Oxygen release from manganese ores relevant for chemical-looping with oxygen uncoupling conditions. Fuel 232:693-703

Publisher's note Springer Nature remains neutral with regard to jurisdictional claims in published maps and institutional affiliations.

\section{Affiliations}

\section{Tobias Mattison ${ }^{1} \cdot$ Fredrik Hildor $^{2} \cdot \mathrm{Ye} \mathrm{Li}^{3} \cdot$ Carl Linderholm $^{1}$}

Carl Linderholm

carl.linderholm@chalmers.se

1 Department of Space, Earth and Environment, Chalmers University of Technology, Gothenburg, Sweden

2 Department of Chemistry and Chemical Engineering, Chalmers University of Technology, Gothenburg, Sweden

3 Department of Thermal Engineering, Tsinghua University, Beijing 100084, China 